\title{
Tourists as Mobile Gamers: Gamification for Tourism Marketing
}

Xu, F; Tian, F.; Buhalis, D.; Weber, J.; Zhang, H. (2016) Tourists as Mobile Gamers, the Gamification for Tourism Marketing. Journal of Travel and Tourism Marketing 33(8):1124-1142

\begin{abstract}
:
Gaming is rapidly developing as a method of dynamic interaction and experience development. This cutting edge concept of gaming has recently been used by some innovative tourism sectors as a marketing tool and as a method of deeper engagement with visitors. However, little is known in the sector about gaming and tourist game players. This research aims to explore the gamification trend and the potential that gaming is offering for experience development and tourism marketing. Through focus group, this paper discusses gaming and tourism, explores what drives tourists to play games. The results suggest tourists' game playing motivation is multi-dimensional. The majority of players would start with a purposive information seeking, then move onto an intrinsic stimulation, such as fun, challenge and achievement. Socialization is also an important dimension and increasingly players will play with locals or fellow travelers. The research demonstrates several implications for tourism marketing and game design.
\end{abstract}

Key words: mobile games; game motivation; tourist players; game based marketing; gamification

\section{Introduction}

Gaming or electronic games (often simply called 'games') provide players an immersive and interactive entertainment experience often through dynamic and real time interaction with their context, local organisations and fellow players. With the rapid development of mobile devices, such as smart phones and tablets, gaming becomes mobile (Gentes, Guyot-Mbodji \& Demeure, 2010) and allows dynamic interaction at the location of the user. Smart phones enable players to interact with their real world environment in real time (Hinske et al., 2007). Researchers suggest that mobile games have changed the game players' experiences in many ways (Blum et al., 2012). One of the fundamental changes is that gaming experiences have been extended into the real world, and are potentially available at any place and at any time (Benford et al., 2005; Grüter, 2008).

Recently, persuasive technologies such as gaming and the application of game elements have been used in a non-gaming context (a term called gamification), such as business, health and education (Xu, Weber, \& Buhalis, 2014). Persuasive technology is broadly defined as technology that is designed to change attitudes or behaviour of users through persuasion and social influence (Bogost, 2007). Persuasive applications are often computerized software or information systems designed to reinforce, change or shape attitudes or behaviours or both, without using coercion or deception (Oinas-Kukkonen \& Harjumaa, 2008).

Gaming, as a cutting-edge concept, is emerging as a useful tool and has been used by some 
tourism organisations for marketing and for dynamic engagement with users. As a new approach to promote tourism destinations, gaming provides tourism organisations and destination marketers an opportunity to create informative and entertaining settings for successful brand awareness, interaction and communication. Indeed, Middleton (1994) mentions that tourist decision making is affected by both formal (e.g. advertising, internet and sale promotion) and informal channels of communication, which form stimulus inputs. As the tourism industry is primarily an experience industry (Pine \& Gilmore, 2011), several researchers have been arguing about the importance of using experiential information in promotional stimuli for tourism marketing (Goossens, 2000; Gretzel, Yuan \& Fesenmaier, 2000; Stamboulis \& Skayannis, 2003). Gaming as a technological tool therefore has the potential to help developing such experiences and supporting dynamic interactions. For example, location based games can be a way of experiencing Points of Interests for tourists through a treasure hunt. 'Tourists can follow a list of recommendations given by a mobile game and can learn something about their environment by solving mini games related to their experiences' (Linaza, Gutierrez \& Garcia, 2014, p.498).

Serious games are designed for purposes other than mere entertainment for players. They primarily perform tasks and achieve objectives that are addressing key user requirements, including education, on the job training, cultural heritage and medical applications. Serious games often collect information about brand consumers, determine behaviour patterns, thought processes, priorities and interests and use gaming technologies and methodologies to engage users/learners/tourists at a deeper level in order to help them conceptualise and improve their experience. An example can be found at Dublin Augmented Reality Project. It is developed to support Dublin's brand development to become the 'innovative city' in Europe (Han, Jung \& Gibson, 2014, p512). The project is funded by Dublin city council to develop a mobile AR application for the tourism industry in Dublin, "which will be applied via tourist trails in various parts of the destination by considering various tourism stakeholders. This application will provide a platform to superimpose tourism relevant information, reconstruct and revive stories of the past, assisting the tourists in creating an emotional experience of the intangible product" (Han et al., 2014, p512). This innovative project has been aimed to be the first European city to implement an AR infrastructure, not only benefiting tourists but also its citizens and other stakeholders.

Gaming is in its infancy in many industries and also in tourism, as very few successful examples have already been established, mainly specialised treasure hunts and cultural heritage applications. Gaming in tourism is a new and emerging area. Technically, it is very challenging in two aspects. One is that the game designers need to understand both the tourists' needs and the gamers' desires, and then blend them seamlessly to deliver a memorable, fun and engaging gaming experiences, for this particular segment; the other is that, from a game programmer's point of view, developing location based tourism games such as those based on Augmented Reality (AR) is more complex because AR still faces some technical issues itself, for example real time calibration Non-technically, the business model of these games needs to be explored and investigated further. Compared with generic or traditional games, the tourism specific games require very specific information of a particular destination which sometimes is difficult to be incorporated into the games. A game company must also take a tourist game's commercial viability into account as the target group of customers/players is relatively small. 
Gradually some serious games are being designed for the purpose of introducing tourism information, specifically targeting tourist players. However, they are not always successful due to a lack of understanding of tourist players (Fernandes, Almeida \& Rosseti, 2013). Compared with traditional game players at home, tourist players are often playing in an unfamiliar environment with a limited time (Fernandes et al., 2013) and they are also interested in their surrounding environment. Although tourists are important users of mobile games, hitherto little is known about their gaming motivation and experiences.

Previous studies on gaming motivations have mainly studied traditional games and games as pure entertainment (e.g. Ryan, Rigby \& Przybylski, 2006). These studies have demonstrated the importance of researching players' motivations. Indeed, a deep understanding of motivations will help game designers create convincing and worthwhile games for users to enhance their experiences.

However, the research on traditional games (de Souza e. Silva 2013) is not sufficient as mobile games are different, they can be played at any time and any place, and the player's interaction with the surrounding environmental via smart phones could result in motivations that differ from other traditional games (Goh et al., 2011), particularly in the case of tourist players. There is very limited research on mobile games (Schonau-Fog, 2011) and whether traditional game play motivation would be suitable to mobile games is unsure.

Through focus group, this research discusses gaming and tourism and introduces the cutting edge concept of game based marketing for tourism. It explores what drives tourists play mobile games on holiday, what are their requirements and discusses whether traditional game play motivation would be suitable for mobile tourist players.

\section{Literature Review}

The concept of gaming

Gaming in this paper concentrates on electronic games, often played on mobile devices and smart phones. Gaming is the running of software artefacts known as electronic games (often simply called 'games'). Traditionally games are played on computers and electronic devices such as smartphones and tablets, providing players an immersive and interactive entertainment experience often through dynamic and real time interaction with their context, local organisations and fellow players (Doughty, 2005). Gaming is regarded as a closed system in which the guidelines have to be clearly stated beforehand (Salen and Zimmermann 2004). McGonigal (2011) suggests that goals, rules, feedback systems and voluntary participation are important characteristics of gaming. Crawford (2011) suggests that a game is a subset of reality in which the players dive in while playing. Juul (2003) adds emotional attachment of a player assigned to the game itself and its specific outcome.

The proliferation of smart phones and tables has empowered mobile gaming and is changing the 
gaming experience. With the popularity of smart phones, tablets and PDAs, gaming experiences become much more mobile and context play a critical background to the gaming experience. Particularly those location-based, GPS supported mobile games, such as Geocaching and Shadow Cities, provide players a more exciting and real experience (Benford, 2012). Location based mobile games have taken the players from the virtual world to a real/mixed world environment (Gentres, Guyot-Mbodji, \& Demeure, 2010; Hinske et al. 2007). Gruter (2008) states mobile games emphasize on mobility and positioning, often using the context of their location as the background for the game. The physical location and the movement of the players are important in location based mobile games (Jacob, 2011). Klopfer \& Squire (2008) observe that mobile gaming is expanding to more context sensitive, supporting game apps that relate the player to his physical location and encourage users to complete local tasks, as well as connect with and compete against other players. The latest generation of smart devices have been introducing gaming experiences into entirely new experiences. From smart phone game apps to online social interaction, technology and social media has made gaming rapidly acceptable for both males and females, young and old as well as people who have never played games before.

\section{Motivation of game players}

Motivation plays an important part in game playing. Ryan et al. (2006) suggest that understanding the motivation of game players is an under-researched area. Boyle et al (2012) state that studies of motives for playing digital games are mainly grounded in rigorous theoretical models, and they are mostly based on satisfaction of needs. The main motivations identified by researchers are summarized in Table 1. Although different methodological approach used, researchers tend to agree that games are used for enjoyment and to satisfy the needs for competence and relatedness.

\section{Insert Table 1 Near Here.}

Bartle's (1996) work on player type is one of the early works exploring player motivation. Based on Massively Multiplayer Online Game (MMOG) players, Bartle divides players into four types, namely: achievers, socialisers, explorers, and killers. The majority of players ( $80 \%$ of the players) are socialisers: they look for social engagement with other people. Achievers are always looking for challenge. Explorers are eager to know the breadth of the game by discovering every angle. While killers, interested in competing with and defeating others, only account for less than $1 \%$ of total game players' population, they are most active and most engaging. Bartle's work has provided an important foundation for many researchers, although the use of Bartle's work applies to MMOG only, whether it is applicable to today's mobile games is uncertain. Given the differences of mobile games, it is necessary to revisit game player's motivation in a mobile context. Nevertheless, Bartle's model on players' type recognizes the need to understand different player's motivation.

Researchers also suggest gender, age, experience and even personality could influence the motivation for playing. Jansz, Avis \& Vosmeer (2010) find that males rate social interaction, fantasy and challenge as more important motivations than females. Olson (2010) agrees that for males, fun, competition, challenge and excitement, relaxation and coping with anger are important 
motives for playing games. Eglesz et al. (2005) find different motivations in different age groups. Younger people tend to look more for sensation seeking motives, while older people (above 30s) tend to try again when they fail. Researchers agree that motivation changes when players become more experienced. Wang \& Chiou (2007) find intrinsic motives are more important to online addictive players, while extrinsic motivation is more important to the non addictives.

Most research on player motivation is based on traditional games. Little is known about mobile game players, and particularly those GPS supported mobile game players, who might have a different motivation due to the context awareness and mobile positioning characteristics of those games (de Souza e Silva 2013). A context or in other words environment can alter significantly the way a user interacts with a mobile game which involves movement, unpredictable states and various physical parameters, like noise and light, limited screen etc. (Rapits, Tselios \& Avouris, 2005). Mobile's location aware capabilities allow users to annotate locations, find other people in the vicinity, and access information connected to specific locations (de Souza e Silva, 2013). Socialization becomes more important for mobile players. The concept of Net locality (Gordon \& de Souza e Silva, 2011) demonstrates the player is part of the local space. However, the distractions of traffic (particularly in urban areas), also constrains the players' movement in the game. Context awareness provides players with information that is highly relevant to their current situation or a personalized context, allowing an effective way and dynamic way to communicate in the game. Researchers also identify that mobile gaming fosters feelings of community and team play (social motivation) and competition (Li \& Counts, 2007; Schønau-Fog, 2011).

Tourism and gaming

The use of games in tourism industry may potentially provide great marketing opportunities. Tourism is an experience industry (Pine \& Gilmore, 2011) that is increasingly based on co-creating personalisable services. New technologies such as social media, smart phones, and gaming provide technological tools for developing such experiences. Indeed, the travel industry has always been one of the first ones to engage new initiatives (Buhalis \& Law 2008). According to World Travel Market Report (2011), gamification is a major trend for the coming years in tourism, which will appeal to consumers across all age demographics.

The current use of gaming by tourism industry can be divided into two types, namely:

1) Social games (play before you are there), based on social media such as Facebook, and are mainly used for brand awareness, to attract potential customers, to build up a destination or a company image. Examples can be found in Thailand (Smile Land Game, 2012), Capetown (The Real Time Report, 2012), Ireland (Tourism Island, 2011) and Nanjing, China (People, 2013) Those games were developed by Destination Management Organizations (DMOs) for destination marketing purposes. Many airlines including KLM, British Airways and Virgin Atlantic have also developed games to engage consumers in branding and marketing exercises.

2) Location-based mobile games (play while you are there) are mainly used to encourage more engagement on site, to enhance tourists on site experiences at the destination in a more fun and informative way (Waltz \& Ballagas 2007). However, "a tourist destination is an extremely rich source of information, supplying tourists at each moment with a continuous flow of images, 
sounds and feelings that cannot be fully simulated by computers" (Linaza et al. 2014 p.498). Most of the existing tourism destination games are based on the game principles of classic treasure hunt. For example, REXplorer aims at persuading on site tourists to explore and enjoy the history of the UNESCO world heritage city of Regensburg, Germany (Waltz \& Ballagas, 2007). The 'Amazing City Game' has been developed in Trondheim, Norway to encourage tourists to enter a knowledge competition tour by solving tasks at different locations (Wu \& Wang 2011). Augmented reality is a popular technique used in location based tourist games to enhance immersive experiences on site (Mashable, 2011) as it enables a blend between virtual and real environments. (Yovcheva et al 2014).

However, these game apps are not always successful. Some fail to engage travellers and often lack fun and sometimes facts about tourist spot. For example, after reviewing 15 mobile advertgames, Celtek (2010) concluded that none of the games gave information about the destination and country except VeGame and Geocaching. Game developers who have technical background sometimes might not be fully aware of the tourists' need and motivation to play. Therefore, a user centred approach in game design is critical (Ermi \& Mayra 2005; Yovcheva et al 2014).

A sufficient understanding of tourist players' motives and gaming experiences will be helpful in the design of these games. Although there are theories on game player motivations, they are not specifically addressed to tourists, thus failed to identify tourists' needs. Research suggests that tourists have the information needs which differ from other players (Youcheva et al. 2014), tourists usually have a limited time (Fernandes et al., 2013), and are not familiar with the location. Therefore, when playing games, tasks need to be less ambiguous and less challenging. Why do tourists play games, when do they play, what type of games do they prefer, what are they expecting from game based marketing are critical aspect of game design.

Gamification in tourism marketing

Game based marketing offers a potential new type of marketing opportunity in tourism. Chaffey \& Ellis-Chadwick (2012) recognize gamification and mobile marketing are important trends of the future of marketing. Digital technology is reshaping the entire marketing mix (Jobber, 2009). In terms of game-based marketing, it adds more fun and personal experience to marketing the product through virtual experiential marketing (Middleton, Fyall \& Morgan, 2009, p.260). Zichermann \& Linder (2010) argue that games are about pleasure, and pleasure is the new marketing element, one extreme powerful dimension of marketing. Games therefore can provide a new and powerful way of interaction and engagement in a fun and rewarding way.

The importance of using experiential information in promoting stimuli for tourism marketing has been recognized by many academics (Huang et al. 2013). Willliams (2006) recommends the use of immersive virtual environment as a new approach to promote tourism sites, offers destination marketers an opportunity to create informative and entertaining settings for successful interaction and communication between the destination and the tourists (Bogdanovych et al. 2007). Berger et al. (2007) note that technologies such as virtual reality allow potential tourists to collect travel information and experience 3D representation of a destination (Hay 2008). The use of games 
offers a variety of benefits for tourism marketing, and can increase brand awareness, attract potential customers, enhance tourists' on site experiences and increase engagement.

Game design can be based on real environments, for example, tourist attractions (as in the case of Thailand \& China). It provides potential visitors an informing and entertaining setting. Games are usually presented with a virtual reality or augmented reality 3D technology providing an immersive and engaging experience with the virtual and real destination (Huang et al. 2013; Yovcheva et al 2014).

Games with an advertising purpose, also known as advergames, are important new types of marketing tool that could offer entertainment to game players in order to make an emotional connection between the game and the brand. Celtek (2010) concludes advantages of using advergames as less annoying and more personalised.

In addition, gaming provides a good opportunity of building an online community as often a sense of community is identified (Fong \& Frost 2009). Buhalis \& Law (2008) recognized virtual communities could have an influence on brand awareness, therefore suggesting it should be used as way to better understanding customers, as well as compensate negative word-of-mouth. Wang et al. (2002) also agree that the brand-building associated with virtual communities can lead to brand awareness and brand loyalty.

The tourism industry provides multi-dimensional and multifaceted experiences (Kim, Ritchie \& Mccormick, 2012; Neuhofer, Buhalis \& Ladkin, 2012). Researchers suggest that leisure experiences are about feeling, fantasy and fun (Holbrook \& Hirschman, 1982), escape and relaxation (Beard \& Ragheb, 1983), entertainment (Pine \& Gilmore, 1999; Farber \& Hall 2007), novelty and surprise (Dunman \& Mattila, 2005). The research on tourist experiences could benefit from gaming research. The enjoyment of playing (Klimmt, 2003) and the desire to continue playing to challenge one's own abilities (Brown \& Vaughn, 2009); the different types of emotions, such as hope, fear, excitement (Zichermann \& Cunningham, 2011); the experiences of fantasy, fun and challenges all contribute to a deep engagement and the addiction of game play and engaging with tourism organisations and destinations.

Researchers argue that with the grown up of a new generation, 'Generation G, who was born after 1998, whose principle form of entertainment is games and who is the first truly mobile and social generation' (Zichermann \& Linder, 2010, p163), the future marketing is facing a new challenge to satisfy this mobile and social generation and to dynamically cocreate products and services.

Tourists' leisure motivations on holiday

Understanding the holiday motivation for tourists and their requirements from tourism products and services is critical. In the field of tourism, study on tourist holiday motivation has been carried on for a long time (Baloglu \& Uysal, 1996; Hsu, Cai, \& Li, 2010). Maslow (1943) suggests that people start with basic low level of physiological need to safety, belonging and love, esteem and self-actualisation. Dann (1977) and Crompton (1979) divide motivations to push and pull factors; 
Beard \& Ragheb (1983) suggest four aspects of motivation: intellectual; social; self-challenge; and stimulus-avoidance. Iso-Ahola's (1982) motivations include escaping and seeking; McIntosh, Geoldner \& Ritchie (1995) suggest motivations as physical, cultural, interpersonal and status and prestige motivations. Holiday motivation referred in this paper is primarily applicable to leisure travellers as business travellers often have no choice of destinations or activities which are determined by meetings, conferences and business agendas. However, even business travellers with a few hours to spend may use a game (such as treasure hunt) to explore a destination at the limited time available or they can play a game before travelling to familiarise themselves with the destination.

Researchers agree that motivation to play games is multi-dimensional. It can be influenced by many factors, such as gender, age, life stage and previous travel experiences (Wagner \& Sherman, 1983; Jang \& Cai, 2002; Jonsson \& Devonish, 2008; Reisinger \& Mavondo, 2001; Pearce \& Lee, 2005). From the above literature, it is obvious there are some overlapping dimensions between a tourist's motivation to travel and a game player's motivation to play games. However, whether those general motivations of game players apply to tourist game players is uncertain. In order to understand tourist players' experiences and behaviour of game-based marketing, it is essential to explore tourist game players' motivations. Figure 1 illustrates the uniqueness of tourists' motivation in using mobile games in comparison with non-tourists based on prior literature

\section{Insert Fig 1 Near Here.}

\section{Methodology}

This research is explorative as it investigates a new and emerging area. It aims to explore how gaming can be used in tourism marketing and how consumers can benefit from gaming whilst travelling. Since this is a new area it needs to be explored in depth and thus qualitative research paradigms are followed. Focus groups have been widely used in social sciences and applied research (Puchta \& Potter 2004). As a qualitative research method, focus groups emphasise group discussions and group interactions, as well as share and compare individual experiences among the participants (Marshall \& Rsooman 2006). The method is usually used for topics that are not well understood to discover new sights. As this paper is to explore the new topic of tourists' opinions and experiences on game-based marketing, its explorative nature and the possibility to generate new discussion, focus groups are considered to be a suitable method for this study. As an exploratory study on the new emerging area of gaming and tourism, representation of the sample as part of the population is not a major concern as the method aims to explore the dimensions and create constructs rather than to measure variables and representation, and a larger scale of quantitative sample will be conducted at the next stage of this project.

Games are extremely popular among students. In this research, a student sample was chosen based on the following considerations:

1) students are advanced users in technology and they are early adopters of technology (Williams, Yee \& Caplan's , 2008) ; Nelson (2006) mentions college students are more likely to be innovators or early adopters of new information technologies than the general population. Arif \& Aslam (2014) also mention university students are early adopters compared with other demographic groups; 
2) students are also main game players as suggested by many game researchers. Griffiths, Davies \& Chappell's (2004) study show that two thirds of game players are under 31 years old, and 29\% of game players are current university students studying undergraduate degree;

3) games are extremely popular among students. Many gaming literatures have used student samples in their study (Lucas \& Sherry 2004; Doughty \& O'Coill, 2005; Eglesz, Fekete, Kiss \& Izsó 2005).

4) today's students are the professional classes of tomorrow so an understanding of their opinions is likely to give some indications of the kind of marketing offers and messages that will be needed to attract them in the future (Xu \& Morgan, 2009). Richards \& Wilson (2003) reported that the 15-25 age group accounts for $20 \%$ of all tourism journeys and that 140 million young people travel every year.

The study was carried out in Nanjing University, China. China is one of the largest mobile users in the world, estimated by marketer that 1 billion mobile users are in China alone (Emarketer, 2013). Nanjing university is a comprehensive university which includes 86 different majors. It covers undergraduates, postgraduates and $\mathrm{PhD}$ students. Students are well equipped with mobile devices. A message to recruit participants was posted on university intranet for two weeks. In order to participate in the focus group, the respondents had to meet the following criteria: (i) currently use a smart phone; (ii) plays PC games or mobile games at least twice a week; (iii) has taken at least one holiday trip during the last 12 months. Finally 26 students who meet the above criteria volunteered. Those 26 students were then divided into groups based on their year of study. As there are only two students from the $3^{\text {rd }}$ year undergraduate program, they were combined with $2^{\text {nd }}$ year students to form a bigger group, this group contains seven students. Profiles of the group participant could be found in Table 2. Four focus groups were conducted, lasting between 1 and 1.5 hours. Each focus group was conducted in a quiet meeting room on campus to avoid any disturbance. One of the authors acted as a moderator in all groups. A research assistant was employed to document the group interaction, including non-verbal communication. At the end of each session, the researcher and the assistant exchanged their ideas on group interaction. This was suggested as the role of moderator and assistant (Krüger, 1998).

At the beginning of the focus group, the interviewer explained the purpose of the research, and each respondent was asked to sign a consent form of confidentiality and anonymity (Creswell, 2008). Each focus group was recorded using a digital voice recorder. Interviews were transcribed verbatim. Data was analysed using thematic analysis (Marshall \& Rossman, 2006). During the interview, a short video of Smile Land Thailand was shown (material was downloaded from YouTube), and respondents were asked about their general use of gaming; gaming activity on holiday; motivation to play games and whether they would play a specific tourism game. The respondents' age ranged from 18 to 28 , covering undergraduate and postgraduate research students (see Profile of Respondents in Table 2). Interaction between the respondents in the groups showed that they helped each other to generate discussion. No major disagreements were discovered in the discussion.

\section{Insert Table 2 Near Here.}




\section{Results and discussion}

It was established that the general use of smart phones and the role of gaming was quite high. Each group was asked about the general usage of their smart phones. Popular themes among the students include making phone calls, sending messages, information search, social networking and other entertainment (Music, photos, reading novel, playing games), although individual usage and preference varied. Surprisingly on average, the most popular usage of smart phones among the students is social networking, information search rather than traditional usage of communication functions (such as phone calls, messages). The popularity of social networking on smart phones has also been proved in other research (Wang \& Fesenmaier, 2013). In daily use, gaming was mentioned by many students as an entertainment function by both males and females in each group, reflecting the popularity of gaming among young people (Zichermann \& Linder, 2010).

Timing is critical and the research aimed to answer when do we play a game on holiday. The groups agreed that people play games mainly before the trip, sometimes during the journey, and maybe after the trip. Most people agreed they used mobile phones to check information about the destination before the trip and they confirmed that if a game can deliver this information, they would have a try. This suggests a possibility of using games as brand awareness before the trip. However they explained that when they are actually at the destination, they prefer to enjoy the real world rather than virtual world. Nevertheless, most of the groups showed interest to the idea of location based mobile games.

'I like playing games, but when I am on holiday, I am busy looking around, enjoy the scenery and local food, I do not have time to play games' (Group D)

'....After a day's tour, you just feel so tired, do not want to play games...' (Group A)

'Location based game is different, it tells you where you are and give you some tasks at the destination. It's interesting as it links with your real environment. It is fun.' (Group B)

All groups agreed that they often played a game on the way to the destination, on a train or flight or waiting in the airport, and the main reason for that is to kill time. This proves previous research on gaming kills time (Chou \& Tsai 2007; Mintel 2009).

Increasingly people play games during holidays and in various locations. Perhaps context determined what types of games players prefer to play on holiday? All groups agreed that while on holiday, due to the limitation of constrains of mobile phones (slow in internet speed, data roaming, small screen etc.), they prefer simple, relaxed, not too challenging games. However, in each group, there seem to be a difference between genders. Boys prefer action and strategy games, while girls prefer brain and leisure games. This is similar with Jansz et al. (2010) research on traditional games.

When considering the reasons to play games on holiday respondents mentioned playing games is mainly to kill time on the way to the destination. 'You can play games on the train, plane on the coach. Because you are bored, and you have nothing to do, this is a good way to kill time, particularly when you are travelling alone.' (Group C)

'Sometimes I arrive too early to the train station, or sometimes my flight is delayed, I usually play 
games (or listening to music) on my mobile to kill the long waiting time'. (Group B)

All groups agreed that when arriving the destination, they prefer sightseeing than games. Some groups added that the only opportunity to play games at the destination is when they come back to the hotel in the evening, they could play games again. 'Some games give you tasks to do everyday; therefore, you need to finish it. And the only time when actually at the destination is to do it when you are in bed in the hotel before you go to sleep' (Group A)

There are several motivations to play a tourism-related game. Each group was given a video of Smileland Thailand marketing campaign of their mobile game, and asked about whether they would play this kind of game, and what might motive them to play. Themes of motivation for playing a tourism game differs from previously mentioned motivations of game players but reflects more the needs of tourists as identified in the following motivations:

\subsubsection{Curiosity}

Curiosity emerged as the most popular theme. Several groups mentioned that as they have never played something like this before, the idea of 'a tourist game' attracts them, and they would definitely have a try.

'As this is a new thing, I have never heard of it, and have never played it, I would like to have a trial to see how it looks like. So, curiosity would be my first motivation. As this is specific tourism context, I would like to see what I can do there in Thailand, shopping, food, etc. What does the Royal Palace look like, you know, that sort of tourist stuff. Explore....' (Group C)

Comments reflect curiosity as the first stage of starting a tourist game, the innovative idea of marketing through a game attracts them to play. This was not mentioned by any previous literature on game playing motivation.

\subsubsection{Exploration}

The second most popular theme is exploration. Groups mentioned that the main motivation would be to see the destination in a virtual world, to gather some information about the destination.

'... a good way to get to know some practical information about the destination, particularly the small attractions, rather than popular, hot spot attractions'. (Group A)

'...practical information to tourists and time saving... you know all about the destination through a game' (Group D)

Although this theme reflects more on the tourist motivation to explore the destination, the fun element of gaming cannot be ignored. Groups mentioned there are lots of ways to know the destination, but playing a game and know the destination is more fun. Compared with other traditional ways of knowing a destination (travel agents, books, internet, etc.), playing a specific destination related game is more fun. Of course, debate on whether the information provided in the game is accurate and updated and whether the users will base their travel decisions on this still remains. Nevertheless, the fun element of exploratory play has been highlighted by the participants. Exploratory play includes a fun element in which participants were seeking entertainment from the game; this again proves Williams' (2006) comment that gaming as a new approach that provides an entertaining setting for tourists. 
4.5.3 Virtual experiences, a mixed feeling of reality and virtual

This is primarily reflecting virtual and augmented reality games. 'When you play this kind of game, if you have already been to the destination, you will have a feeling of real and virtual, this is a wonderful feeling and exciting experience. And if you visit the destination after you played the game, you will also remember how you played in the game, you might wonder am I in the virtual world or real world (laughs). I really look forward to playing this game as I have been to some places in Thailand'. ( Group D)

Comments confirm the potential influence such games could bring to enhance tourists' experiences. This echoes various researchers that gaming can contribute to tourist experiences. Waltz \& Ballagas (2007) suggest gaming can be used to inspire, educate and train tourists.

\subsubsection{Socializing}

Socializing refers to getting to know some people who might also want to go to the destination or local people who live at the destination. This may contribute to co-creating of tourism products with fellow travellers or with local residents. It was also a popular theme, particularly mentioned by females in the group.

If they provide a platform to allow game players to communicate with each other, you might be able to meet some people to go to the destination together. Saying buying a group ticket to get into the attraction or something' (Group A)

"I think it would be good to get to know something about the local people there, to ask them (local residents in the game) questions, to see their dress code, their local food. Sometimes on holiday, particularly if it is a package holiday, you don't have much opportunity to ask the local people, as everything has been arranged for you. (Group B)

Here, socialization includes socializing with potential tourists and with online local residents. The first type of socializing may result in exchanging ideas, perhaps meeting at the destination, travel in company, sharing costs while the second type of interaction will result in learning more about the destination and the local community. The theme of socializing reflects the desire to establish new or maintain existing social relationship, it supports Lin \& Lin's (2011) opinion that online community is important as a platform of socializing in games. Meanwhile, socialization is also an important dimension as a tourist holiday motivation as suggested by many researchers (Beard \& Ragheb, 1983; McIntosh et al. 1995). Therefore, this dimension of socialization reflects both tourists and game players' motivation and can further lead to cocreation of tourist experiences.

\subsubsection{Fun: a fun way to know the destination}

Gaming can also add pure fun in the travel experience as it animates the travel experience and enables users to engage with the destination in an interactive way. This may be a better way to show the different elements of the destination and to animate certain aspects. 'Unlike reading a guidebook or search online information and filter those information to specific destination, I think it is fun to play a game and get to know the destination. Very useful.' (Group C)

'If it is well designed, it would be fun as well. As everyone who plays a game is based on it is fun. Otherwise, people would quit quickly after a few trial'. (Group C) 
It is a better way to show a destination to friends. Traditionally you sent photos to your friend, now I invite you to play the game and show you where I have exactly been, what does it look like. You know, it is fun.' (Group D)

'Years later, when I am older, I can show it to my son that I have been to the places of your game...' (Group D)

Comments suggest that fun is a fundamental dimension of game playing motivation. This echoes Zichermann \& Linder's (2010) opinion that pleasure could be a powerful dimension of marketing. It also reflects fun as a useful element in virtual experimental marketing (Middleton, Fyall \& Morgan 2009). This theme was highlighted by both male and female respondents.

\subsubsection{Challenge and achievement:}

Gaming also includes the challenge and achievement and these elements were also mentioned by a few students. A tourism game may include a challenge such as visit a number of attractions in a limited period of time or identify a number of interlinked monuments. As a reward to mark achievement games may collect points or badges or some other rewards. The level of difficulty may vary and the challenge should lead to a reward for the player achievement. 'You might start with basic information search, but in the end, it is still a game. I guess most people who play games are like me, looking for some kind of achievement. Yes, if there is some challenge there, not so easily be conquered then I will be interested. Otherwise, you play a few times before you go to the destination, then you will never come back to play again' (Group D).

Comments suggest that dimensions of challenge and achievement of traditional games also apply here, but are not as popular as other dimensions. Challenge and achievement, together with competition, are intrinsic motivations. They support the flow of the game, and are considered fundamental motivations in traditional game play (Deci \& Ryan, 1985; Lucas \& Sherry, 2004; Ryan et al., 2006; Yee, 2006; Li \& Counts, 2007).

Figure 2 summarizes the main motivation of playing a tourism game. As illustrated, the basic motivation for playing a tourism game is curiosity. This can be developed to a cutting edge way of tourism marketing where tourism organisations engage players and support them to explore tourism products and destinations. Explore the destination is also a popular theme where players are keen to virtual explore a destination before arrival but also use augmented reality games to add information and fun to their real life experience during their travel experience. These motivations might co-exist at the same time, as gaming motivation can be multi-dimensional. The popular sensation seeking motivation in game players (See Table 1) is not a popular choice here. Rather the intellectual motivations of a tourist (Beard \& Ragheb 1983), to learn, explore and discover new things, were highlighted in the findings, reflecting Iso-Ahola's (1982) seeking dimension of tourists' motivation. Tourism games can be very purposive, as tourist game players want to know more about the destination. The socialization motivation reflects the possible encounter between players with fellow players or tourists as well as with local residents. This can lead to cocreation of tourism experiences with local residents and also among tourists themselves. The intrinsic motivation (Fun\& fantasy; challenge $\&$ achievement) seem to support the flow of the game. When players are becoming more experienced they are looking for more fun and challenges. This has been verified in both situations, playing a general game and playing tourism games. Overall, the respondents identified clear potential in games as a way of engaging with tourism organisations 
and destinations and suggested that if they are designed properly they can clearly enhance their tourism experience before, during and after their visit.

\section{Insert Fig 2 Near Here.}

\section{Conclusion}

Being one of the world's largest and most pervasive industries, the travel and tourism sector is as exposed as any other to the forces of change that are being brought about rapid developments in the Information and Communication Technologies (ICT) arena (Buhalis, 2003, Buhalis \& Law, 2008). Destinations around the world, are investing more on how to use ICT in destination management and marketing. Gaming represents one of the most promising ICT technologies that offer benefits in various areas such as entertainment, education (interpretation), and cocreating of tourism experiences. Gaming can enhance tourist's interest to the destination, providing experiences and knowledge which otherwise are not available, thus co-creating a personal experience during the visit. Engaging other players and locals can enhance this experience even more and influence how a people interact with destinations at a large scale.

Gaming motivation has always been an important topic for research. Understanding the game playing motivation can be useful in design specific games. This paper makes an important contribution by identifying motivation for gaming tourists. The main motivation to play a tourism game is to gain practical information about the destination before, during and after the visit and to socialize with other people. The mixed feeling of playing games in a virtual and real environment (fantasy and fun) is also important. The usual motivation of playing games such as killing time (Chou \& Tsai, 2007; Mintel, 2012) is only important in this case during the transit period, as many tourists who play games would be seeking purposive information, to prepare for the holiday or to enhance their experience on location. The motivations identified in this study reflect a mixture of tourists' needs and motivation (Beard \& Ragheb, 1983; Dann, 1977; Crompton, 1979). They suggest that tourist players might start with a basic information seeking purpose but when they get more experienced in the game, they may seek more challenges and achievements, reflecting some of the intrinsic motivations of game play, supporting Wan \& Chiou's (2007) study.

It is evident that gaming can create a new industry paradigm by engaging tourists in a dynamic, personalized and contextualized experiences. Understanding the tourism players' motivations is critical for both tourism marketers and game designers, as this can help them develop suitable games and experiences using cutting edge technologies.

Gaming can engage tourists in a fun, informative and memorable way through their entire travel experience before, during and after the trip.

Before travelling, gaming can offer an innovative way of marketing a destination and not only attract many potential tourists but also enable them to engage with the destination at a deeper level. Game based marketing has great potential to attract tourists attention and to increase brand awareness. As players are looking for information about the destination, gaming can allow them to explore specialised aspects and assist them to develop their prospective experience. Therefore, the 
purposive feeding of destination information through highly interactive and customisable games is very important. Marketers can design their game based on specific attractions and facilities (Huang et al., 2013), particularly those less known spots. They can also design games to allow players to explore special interest such as archaeology, bird-watching or gastronomy, in a way to prepare a more rewarding visit. This new marketing methods may provides a great opportunity for those small tourism destinations and businesses as well as less known spots as it is an innovative and relatively inexpensive way of marketing.

During the trip, games can be used to kill time on the transit area. They can also add more fun of the journey and enhance tourist onsite experiences. Particularly location-based games and augmented reality games can encourage tourist players to interact with the surrounding physical environment, to learn more facts about the spot, to specialize their visit to their interests, and to enrich a more dynamic and real experience (Waltz \& Ballagas, 2007). Gaming may give tourist players a real, personalized, fun and fantasy experience by making them feel that they are actually in the game themselves, rather than being a separate, exterior entity. Games can also help tourists to develop an emotional attachment of emersion to the destination (Klopfer and Squire, 2008). The results highlight the opportunity of socialising with both other tourist players and local resident players. Hence games can emerge as online platforms to help establishing new or maintain existing social relationships (Chou \& Tsai, 2007) and support value cocreation. This element of socializing is a key dimension of tourist motivation, as suggested by many researchers (Iso-Ahola, 1982; Beard \& Ragheb, 1983).

After the trip, games are mainly used to recall the journey and show off to other people. They can also support players to further engage with the destination and expand elements in depth. But the attractiveness of game playing can always cause players to continue playing and engage further with tourism organisations and destinations. Game players are usually looking for challenges and pursue a sense of achievement in a virtual world. A well-designed game can always trigger players to continue playing and attracts them into an emotional emersion into the virtual world. A number of challenges can also intrigue them to continue playing towards achieving certain benefits and recognition. Rewards in the form of free holidays, meals, entry to attractions can provide the motivation and the challenge to continue the player involvement and stimulate repeat visits. Juul (2003) and Lucas \& Sherry (2004) suggest intrinsic motivation contributes to the flow of the game. Rewards, points are linked to extrinsic motivations of game play, while social connection, challenge are linked with intrinsic motivation. Nicholson (2012) suggests the integration of a User-Centred Design (UCD) approach to identify player's interests, social boundaries and competences is important to address to intrinsic motivation. In a tourism mobile game, virtual rewards can be transferred into real world rewards, such as coupons of the shopping centre, loyalty cards of the restaurant, free entrance of the theme park. The context awareness (such as personal preferences of sights, food, etc.) in the game allows destination marketers to deliver a highly personalized experience to address individual tourist's motivation. After-trip play could also contribute to tourism marketing by engaging gamers and making them ambassadors for the tourism organization and destination. As tourists have already been to the destination, the mixed feeling of reality and virtual engaging when recalling the trip, can enhance tourists' satisfaction, keep the destination to their memory and help them to recommend it to other people. 
Motivations for game playing have always been an important topic for research. Through understanding these motivations, game companies develop games based on specific demands. The findings of this study suggest a UCD approach is important when designing games. Schell (2008) suggests one of the basic elements for game design is the 'Goals' - our findings on the motivations of tourist game players directly contribute to this element. For tourism specific games, it is crucial to feed tourist players accurate information about the destination to satisfy the players' initial motivation - purposive information seeking. With clear 'Goals' in mind the game designers are more likely able to produce a game which is attractive and educative to the tourist players.

When designing a specific tourism game, destination marketers and designers should work closely with each other, consider carefully the above mentioned specific motivations for playing a tourist game. They should also explore the latest technological developments in both gaming and smart mobile devices to ensure that all capabilities are utilized to maximize the interactivity and engagement. Only when tourist players' motivation is fully understood by game designers and the informational and experiential motivations supported by tourism marketers, a game can become attractive and desirable to tourist players.

This research is an exploratory study to explore the motivations of players and the opportunity to use games for tourism marketing. It uses a qualitative method to explore students players opinions, as most advanced gamers. As the research was untaken before the demonstrated game was officially available, this is a limitation in our research. As suggested, there are many factors that might influence a game play motivation, which include both external and internal factors. Future research could use the results of this research to develop constructs to be surveyed, test the conceptual model quantitatively and identify which of those key factors play a higher role for each market segment affected. A quantitative method could also be used to test the gender, age and cultural differences of tourist game players. In this study, the focus group was used to explore students' opinion of the game, future research could also use an experimental method to investigate the tourists' experiences after game playing, for example, their learning about the destination and how that would enhance their motivation of visit. Future research can also concentrate on location based and augmented location games for gamers that are playing games whilst at the destination. The papers offers a significant contribution in understanding how gaming can contribute to tourism marketing and help promoting tourism organisations and destinations through deep engagement with tourist players before during and after their visit.

\section{REFERENCES}

Arif,I., \& Aslam,W. (2014). Students' dependence on smart-phones and its effect on purchase behavior. MPRA paper No. 58919, Aug 2014.

Baloglu, S. \& McCleary, K.W. (1999). US international pleasure traveler's image of four Mediterranean destinations: a comparison of visitors and nonvisitors. Journal of Travel Research 38(2): 144-152.

Bartle, R. A. (1996). Hearts, clubs, diamonds, spades: players who suit MUDs. Retrieved from http://www.mud.co.uk/richard/hcds.htm

Benford, S., Magerkurth, C., \& Ljungstrand, P. (2005). Bridging the physical and digital in pervasive 
gaming. Communications of the ACM, 48(3), 54-57.

Benford, S. (2012). Future location-based experiences JISC technology and standards. Watch, 1-17 http://www.jisc.ac.uk/media/documents/techwatch/jisctsw_05_01.pdf Retrieved from 11 Dec, 2013.

Beard, J., \& Ragheb, M.G. (1983). Measuring leisure motivation. Journal of Leisure Research, 15 (3), 219-228.

Berger, H., Dittenbach, M., Merkl, D., Bogdanovych, A., Simoff, S., \& Sierra, C. (2007). Opening new dimensions for e-tourism. Journal of the Reality Society, 11 (2-3): 75-87.

Bogdanovych, A., Esteva, N., Gu, M., Simoff, S., Maher, M. L., \& Smith. G. (2007). The role of online travel agents in the experience economy. In Proceedings of the 14th international conference on information technology in tourism ENTER, Ljubljana, Slovenia, January 24-26.

Bogost, I. (2007). Persuasive Games: The Expressive Power of Videogames. MIT Press.

Boyle, E.A., Connelly, T. M.,Hainey, T., \& Boyle, J.M. (2012). Engagement in Digital Entertainment Games. Computers in Human Behavior 28, 771-780.

Blum, L., Wetzel, R., Mccall, R., Oppermann, L., \& Broll, W. (2012). The final timewarp: Using form and content to support player experience and presence when designing location-aware mobile augmented reality games. Proceedings of the designing interactive systems conference 711-720

Buhalis, D., \& Law, R. (2008). Progress in tourism management: 20 years on and 10 years after the internet: the state of etourism research. Tourism Management

Buhalis, D. (2003). eTourism: information technology for strategic tourism management, Pearson (Financial Times/Prentice Hall), London

Brown, V. R., \& Vaughn, E. D. (2011). The writing on the (Facebook) wall: The use of social networking sites in hiring decisions. Journal of Business and Psychology, 26(2), 219-225.

Carrigy, T., Naliuka, K., Paterson, N., \& Haahr, M. (2010). Design and evaluation of player experience of a location-based mobile game. In: Proceedings of the 6th Nordic Conference on Human-Computer Interaction: Extending Boundaries, Reykjavik, Iceland.

Celtek, E. (2010). Mobile advergames in tourism marketing. Journal of Vacation Marketing, 16, $267-281$

Chaffey, D. (2004). E-business and e-commerce management, London, UK: Financial Times-Prentice Hall.

Chaffery, D. \& Ellis-Chadwick, F. (2012). Digital marketing, strategy, implementation and practice. $5^{\text {th }}$ edn. Pearson. UK

Chan, N.L. \& Guillet, B.D. (2011). Investigation of Social Media Marketing: How Does the Hotel Industry in Hong Kong Perform in Marketing on Social Media Websites? Journal of Travel and Tourism marketing, 28(4): 345-368

Chou, C., \& Tsai, M.J. (2007). Gender differences in Taiwan high school students' computer game playing. Computers in Human Behavior, 23, 812-824.

Crawford, C. (2011). The art of computer game design. 2nd ed.

Creswell, J.W. (2008). Research design: Qualitative, quantitative, and mixed methods approaches, London: Sage.

Crompton, J. (1979). Motivation for pleasure vacation. Annals of Tourism Research, 6(4), 408-424.

Dann, G. (1977). Anomies, ego-enhancement and tourism. Annals of Tourism Research, 4(4), 184-194. 
De Carvalho, R. \& Ishitani, L., (2012). Motivational factors for mobile serious games for elderly users. Paper presented at the Proceedings of XI SB Games 2012, Brasilia, Brazil.

Deci, E. L., \& Ryan, R. M., (1985). Intrinsic motivation and self-determination in human behavior. New York: Plenum Publishing Co

de Souza e Silva, A., (2013). Location-aware mobile technologies: Historical, social and spatial approaches. Mobile Media \& Communication, 1 (1), 116-121.

Doughty, M. \& O’Coill, C. (2005). Collaborative Software Environments and Participatory Design, Proceedings of IADIS International Conference on Web Based Communities, Algarve, Portugal, 23-25 February, 2005, 303-306.

Dunman, T., \& Mattila, A.S. (2005). The role of affective factors on perceived cruise vacation value. Tourism Management, 26, 311-323.

Eglesz, D., Fekete, S., Kiss, O. E., \& Izsó, L. (2005). Computer games are fun? On professional games and players’ motivations. Educational Media International, 42(2), 117-124.

Emarketer (2013). Asia-Pacific Reaches Whopping 2.5 Billion Mobile Phone Users http://www.emarketer.com/Article/Asia-Pacific-Reaches-Whopping-25-Billion-Mobile-Phone-Us ers/1010247 accessed 27 Nov, 2013

Engl, S. \& Nacke, L. E. (2012). Contextual influences on mobile player experience - a game user experience model. Entertainment Computing.

Farber, M. E. \& Hall, T. E. (2007). Emotion and environment: visitors extraordinary experiences along the Dalton highway in Alaska. Journal of Leisure Research, 39(2), 248-270.

Fernandes, R. P. A., Almeida, J. E., \&Rosseti, R. J. F. (2013). A collaborative tourist system using Serious Games. Advances in Intelligent Systems and Computing, 206, 725-734.

Ermi, L. \& Mäyrä, F. (2005). Player-Centred Game Design: Experiences in Using Scenario Study to Inform Mobile Game Design. The International Journal of Computer Game Research, 5 (1), http://www.researchgate.net/profile/Frans Maeyrae/publication/220200719 Player-Centred Gam e Design Experiences in Using Scenario Study to Inform Mobile Game Design/links/09e41 50c5499d39f10000000.pdf accessed 03 May, 2015

Fong, P. \& Frost, P. M. (2009). The Social benefits of computer games. Proceedings of the 44th Annual APS conference (2009), pp. 62 - 65

Frostling-Henningsson, M. (2009). "First-Person Shooter Games as a Way of Connecting to People: 'Brothers in Blood','. CyberPsychology \& Behavior (numera CyberPsychology, Behavior, and Social Networking), 12(5): 557-562.

Gentres, A., Guyot-Mbodji, A. \& Demeure, I. (2010). Gaming on the move: Urban experience as a new paradigm for mobile pervasive game design. Multimedia Systems, 16, 43-55.

Goossens, G. (2000). Tourism information and pleasure motivation. Annals of Tourism Research, 27(2), 301-321.

Gloor, P. (2000). Making the e-business transformation, New York, NY: Springer.

Goh, D.H., Ang, R.P., Lee, C.S. \& Chua, A.Y.K. (2011). Fight or unite: investigating game genres for image tagging, Journal of the American Society for Information Science and Technology, 62(7): 1311-1324.

Gordon, E., \& de Souza e Silva, A. (2011). Net locality: Why location matters in a networked world. Boston, MA: Blackwell Publishers.

Gretzel, U., Yuan, Y.-L., \& Fesenmaier, D. R. (2000). Preparing for the new economy: advertising strategies and change in destination marketing organizations. Journal of Travel Research, 39, 
146-156.

Griffiths, M. D., Davies, M. N.O., \& Chappell, D. (2004) Demographic Factors and Playing Variables in Online Computer Gaming. Cyber Psychology \& Behavior, 7(4),479-487

Grüter, B. (2008). Studying mobile gaming experience. Paper presented at the Workshop: Evaluating Player Experiences in Location Aware Games, HCI 2008, Culture, Creativity, Interaction September 1-5, 2008, Liverpool. John Moores University, UK.

Han, D., Jung, T. \& Gibson, A. (2014). Dublin AR: Implementing Augmented Reality (AR) in Tourism In Z.Xiang and I. Tussyadiah (eds)., Information and Communication Technologies in Tourism 2014, Springer Computer Science, Wien, New York, 511-523

Hay, B. (2008). Where the bloody hell are we? Fantasy tourism and second life. In proceedings of the CAUTHE 2008 conference.

Hinske, S., Lampe, M., Magerkurth, C., \& Röcker, C. (2007). Classifying pervasive games: On pervasive computing and mixed reality. In: Concepts and technologies for pervasive games - a reader for pervasive gaming research Vol. 1.

Holbrook, M. B, \& Hirschman, E. C. (1982). The experiential aspects of consumption: Fantasies, feelings and fun, Journal of Consumer Research, 9 (2), 132-139.

Huang, Y., Backman, S. J., Backman, K. F., \& Moore, D., (2013). Exploring user acceptance of 3d virtual worlds in travel and tourism marketing. Tourism Management, 36, 490-501.

Hsu, C. H. C., Cai, L.A., \& Li, M. (2010). Expectation, motivation, and attitude: a tourist behaviour model. Journal of Travel Research, 49(3), 282-296.

Iso-Ahola, S.E., (1982). Toward a social psychological theory of tourism motivation: A rejoinder. Annals of Tourism Research, 9, 256-262.

Jang, S., \& Cai, L. A. (2002). Travel motivations and destination choice: A study of British outbound market. Journal of Travel \& Tourism Marketing, 13(3), 111-133.

Jansz, J., Avis, C., \& Vosmeer, M. (2010). Playing The Sims2: An exploration of gender differences in players' motivations and patterns of play. New Media \& Society, 12(2), 235-251.

Jacob, J. (2011). A Mobile Location-Based Game Framework. Paper presented at the DSIE'11 - 6th Doctoral Symposium on Informatics Engineering, Porto, Portugal.

Jobber, D. (2009). Principles and practices of marketing. 6th edn McGraw-Hill Higher Education.

Jonsson, C. \& Devonish, D. (2008). Does nationality, gender and age affect travel motivation? A case of visitors to the Caribbean island of Barbados. International Journal of Tourism Marketing, 25(3-4), 398-408.

Juul, J. (2003). The game, the player, the world: Looking for a heart of gameness. Paper presented at the Level Up: Digital Games Research Conference Proceedings, Utrecht, Netherlands.

Kim, H., Ritchie, J. R. \& Mccormick, B. (2012). Development of a scale to measure memorable tourism experience. Journal of Travel Research, 51(1), 12-25.

Klimmt, C. (2003, November). Dimensions and determinants of the enjoyment of playing digital games: A three-level model. In Level up: Digital games research conference (Vol. 246, p. 257). Utrecht: Faculty of Arts, Utrecht University.

Klopfer, E. \& Squire, K. (2008). Environmental detectives - the development of an augmented reality platform for environmental simulations. Educational Technology Research and Development, 56 (2), 203-228.

Krüger, R.A. (1998). Moderating focus group. Thousand oaks: CA, Sage.

Li, K. A., \& Counts, S. (2007). Exploring social interaction and attributes of casual multiplayer mobile 
gaming. In: Proceedings of the 4th International Conference on Mobile Technology, Applications and Systems and the 1st International Symposium on Computer Human Interaction in Mobile Technology, Singapore: ACM.

Lin, T.-M., Chen, S.-C., \& Kuo, P.-J. (2011). Motivations for game-playing on mobile devices: Using smartphone as an example. In: Proceedings of the 6th international conference on E-learning and games, edutainment technologies, Taipei, Taiwan: Springer Verlag.

Lin, Y.-L., \& Lin, H.-W. (2011). A study on the goal value for massively multiplayer online role-playing games players. Computers in Human Behavior, 27, 2153 - 2160.

Linaza, M. T.; Gutierrez, A., \& Garcia A. (2014). Pervasive augmented reality games to experience tourism destinations. In X. Zheng \& I.,Tussyadiah, (eds), Information and Communication Techonologies in Tourism, Springer, pp.497-510.

Lucas, K., \& Sherry, J. (2004) Sex differences in video game play: a communication-based explanation. Communication Research, 31(5): 499-523

Marshall, C. \& Rossman G. B. (2006). Designing qualitative research (4th edition). California: Sage.

Mashable (2011). Why location-based gaming is the next killer app, http://mashable.com/2011/07/24/location-based-gaming/ accessed 03 June, 2013

Maslow, A. H. (1943). A theory of human motivation. Psychological Review, 50(4), 370.

McGonigal, J. (2011). Reality is broken: Why games make us better and how they can change the world. New York, USA: Vintage.

McIntosh, R. W., Goeldner, C. R. \& Ritchie, J. R.B (1995). Tourism: principles, practices, philosophies. $167-190$

Mintel (2009). Gaming in the interactive world. Aug 2009

Mintel (2012). Mobile application gaming. Executive summary report- UK Feb, 2012.

Middleton, V. T. C., (1994). Marketing in travel and tourism. Oxford; Boston: Butterworth-Heinemann.

Middleton, Fyall, A. \& Morgan, M. (2009). Marketing in travel and tourism. $4^{\text {th }}$ edn. Butterworth-Heinemann Oxford, UK

Nelson, M. R. (2006). Digital Content Delivery Trends in Higher Education. Research Bulletin, Centre for Applied Research, 25(9), https://net.educause.edu/ir/library/pdf/ERB0609.pdf accessed 14 April, 2015

Neuhofer, B., Buhalis, D., \& Ladkin, A., (2012). Conceptualising technology enhanced destination experiences. Journal of Destination Marketing \& Management, 1 (1-2), 36-46.

Oinas-Kukkonen, H. \& Harjumaa, M. (2008). "Towards Deeper Understanding of Persuasion in Software and Information Systems“ in Proceedings of The First International Conference on Advances in Human-Computer Interaction (ACHI 2008), 200-205.

Olson, C. K. (2010). Children's motivations for video game play in the context of normal development. Review of General Psychology, 14(2), 180-187.

Paras, B. \& Bizzochi, J. (2005). Game, motivation, and effective learning: An integrated model for educational game design. Paper presented at the Proceedings of DiGRA 2005 Conference: Changing Views - Worlds in Play.

Pearce, P., \& Lee, U. (2005). Developing the travel career approach to tourist motivation. Journal of Travel Research, 43(3), 226-237.

People, (2013). http://js.people.com.cn/html/2013/03/17/214163.html 17 March, 2013 accessed 18 March, 2013. 
Pine, B. J., \& Gilmore, J. H. (1999). The experience economy: work is theatre and every business is a stage. Boston Mass: HBS Press.

Pine, B. J. \& Gilmore, J. H. (2011). The experience economy, updated version. Harvard Business School Publishing, Massachusetts

Puchta, C. \& Potter J. (2004). Focus group practice. London: Sage.

Rapits, D.; Tselios, N., Avouris, N. (2005). Context design for mobile applications for museum, a survey of existing practices Proceedings of the 7th Conference on Human-Computer Interaction with Mobile Devices and Services, Mobile HCI 2005, 2005, Salzburg, Austria, September 19-22, 2005 Source: DBLP DOI: 10.1145/1085777.1085803

Ryan, R. M., Rigby, C. S., \& Przybylski, A. (2006). The motivational pull of video games: A self-determination theory approach. Motivation and Emotion, 30, 347-363.

Richards, G. \& Wilson, J. (2003). New Horizons in Independent Youth and Student Travel. A report for the International Student Travel Confederation (ISTC) and the Association of Tourism and Leisure Education (ATLAS). International Student Travel Confederation: Amsterdam.

Reisinger, Y., \& Mavondo, F. (2005). Travel anxiety and intentions to travel internationally: Implications of travel risk perception. Journal of Travel Research, 43(3), 212-225.

Salen, K. \& Zimmerman, E. (2004). Rules of play: Game design fundamentals. Cambridge, Mass.: MIT Press.

Schell, J. (2008). The Art of Game Design, the Book of Lences. San Francisco, CA: Morgan Kaufmann

Schønau-Fog, H. (2011). The Player Engagement Process - An Exploration of Continuation Desire in Digital Games. Eludamos. Journal for Computer Game Culture, 6 (1), 53-70.

Smile Land Game (2012). http://www.smilelandgame.com/ accessed 12 Jan, 2014

Stamboulis, Y., \& Skayannis, P. (2003). Innovation strategies and technology for experience-based tourism. Tourism Management, 24(1), 35-43.

Szalavári, Z., Eckstein, E., Gervautz, M. (1998). Collaborative Gaming in Augmented Reality. VRST ' 98 Proceedings of the ACM, symposium on virtual reality software and technology. 195-204

The Real time report (2012). http://therealtimereport.com/2013/02/05/tourism-marketing-how-a-facebook-game-lured-fans-tocape-town/ accessed 01 March, 2013

Tourism Ireland (2011) http://www.tourismireland.com/Home!/About-Us/Press-Releases/2011/Tourism-Ireland-Launche s-Game-on-Facebook---First.aspx) accessed 01 March, 2013

Tychsen, A., Hitchens, M., \& Brolund,T. (2008). Motivations for play in computer role-playing games. In: Proceedings of the 2008 Conference on Future Play: Research, Play, Share, Toronto, Ontario, Canada: ACM. 57-64

Waltz, S. P. \& Ballagas, R. (2007). Pervasive Persuasive: A Rhetorical Design Approach to a Location-Based Spell-Casting Game for Tourists.” In: Proceedings of Situated Play. DiGRA 2007 - The 3rd International Digital Games Research Conference, Tokyo, September 24-28, 2007. pp. 489-497.

Wan, C.-S., \& Chiou, W.-B., (2007). The motivations of adolescents who are addictedto online games: A cognitive perspective. Adolescence, 42(165), 179-197.

Wang, D. \& Fesenmaier, D. (2013). Transforming the travel experiences: the use of smart phones for travel. In L. Cantoni \& X. Zheng (eds) Information and Communication Technologies in Tourism 
2013 Springer-Verlag Berlin, 58-69

Wang, C., Zhang, P., Choi, R., \& D'Eredita, M. (2002). Understanding consumers attitude toward advertising. AMCIS 2002 Proceedings, 158.

Williams, A. (2006). Tourism and hospitality marketing: fantasy, feeling and fun. International Journal of Contemporary Hospitality Management, 18(6),482-495

Williams, D., Yee, N., Caplan S. E. (2008) Who plays, how much, and why? Debunking the stereotypical gamer profile, Journal of Computer-Mediated Communication, 13(4), 993-1018

Yee, N. (2006). Motivations for play in online games. Cyber Psychology and Behaviour, 9(6), 772-775.

Yee, N., Ducheneaut, N., \& Nelson, L. (2012). Online gaming motivation scale: Development and validation. In: CHI 2012, Austin, Texas, USA.

Yovcheva, Z., Buhalis, D., Gatzidis, C.\& van Elzakker, C. (2014). Empirical evaluation of smartphone Augmented Reality browsers in urban tourism destination context. International Journal of Mobile Human Computer Interaction, 6 (2), 10-31.

Zhou, T. (2012). Understanding the effect of flow on user adoption of mobile games. Personal and Ubiquitous Computing, Springer.

Zichermann, G. \& Linder, J. (2010). Game based marketing, John Wiley \& Sons Inc. New Jersey.

Wu, B., \& Wang, A.I., (2011). A pervasive game to know your city better. In Proceedings of the 2011 IEEE International Games Innovation Conference (P117-120). IEEE Computer Society. Washington, DC.

$\mathrm{Xu}$, F, \& Morgan, M. (2009). Student Travel Behavior-A Cross Cultural Comparison. International Journal of Tourism Research 11(3): 255-268

$\mathrm{Xu}, \mathrm{F}$. , Webber, J., \& Buhalis, D. (2014). The Gamification of Tourism. In Information and Communication Technologies in Tourism 2014 Springer Computer Science, Wien, New York, 525-537.

Zichermann, G., \& Cunningham, C. (2011). Gamification by design: Implementing game mechanics in web and mobile apps. O'Reilly Media, Incorporated. 